\title{
The Ghost That Slayed the MANDATE
}

\author{
Kevin C. Walsh*
}

Virginia v. Sebelius is a federal lawsuit in which Virginia has challenged President Obama's signature legislative initiative of health care reform. Virginia has sought declaratory and injunctive relief to vindicate a state statute declaring that no Virginia resident shall be required to buy health insurance. To defend this state law from the preemptive effect of federal law, Virginia has contended that the federal legislation's individual mandate to buy health insurance is unconstitutional. Virginia's lawsuit has been one of the most closely followed and political$l y$ salient federal cases in recent times. Yet the very features of the case that have contributed to its political salience also require its dismissal for lack of statutory subject matter jurisdiction. The Supreme Court has placed limits on statutory subject matter jurisdiction over declaratory judgment actions in which a state seeks a declaration that a state statute is not preempted by federal law-precisely the relief sought in Virginia v. Sebelius. These statutory limits are a sea wall; they keep out, on statutory grounds, some suits that should otherwise be kept out on Article III grounds. The statutory and constitutional limits on federal jurisdiction over suits like Virginia v. Sebelius insulate federal courts from the strong political forces surrounding lawsuits that follow from state statutes designed to create federal jurisdiction over constitutional challenges by states to federal law. This Article identifies previously neglected jurisdictional limits, shows why they demand dismissal of Virginia v. Sebelius, and explains why it is appropriate for federal courts to be closed to suits of this type.

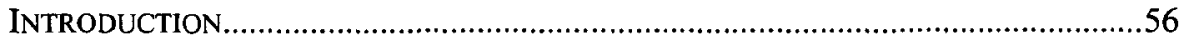

I. Virginia's PuRsuit of Health CARE FreEdom In FEdERAL COURT ..............58

II. NO, VIRGINIA, THERE IS No FEDERAL JURISDICTION .................................60

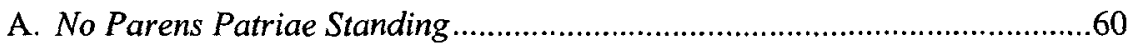

B. No Statutory Subject Matter Jurisdiction .............................................61

C. No Article III Case of Actual Controversy ................................................67

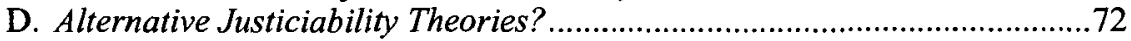

* Assistant Professor, University of Richmond School of Law. Thank you to William Baude, Joseph Blocher, Samuel Bray, Richard Fallon, Jim Gibson, Abbe Gluck, Corinna Lain, Allison Orr Larsen, Caleb Nelson, James Pfander, Jack Preis, and Carl Tobias for valuable feedback and helpful comments on earlier versions of this Article. Thank you, as well, to Erin Barclay, Andrew Fulwider, Michael Matheson, and Amy Weiss for superb research assistance. 
III. THE INSULATION ARISING OUT OF INCIDENTAL REVIEW …............................78

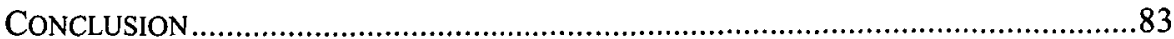

POSTSCRIPT: A REPLY TO VIRGINIA'S MANDATE-CHALLENGE TRIUMVIRATE ........85

\section{INTRODUCTION}

The situation presented by a State's suit for a declaration of the validity of state law is ... not within the original jurisdiction of the United States district courts. 1

It must be remembered that advisory opinions are not merely advisory opinions. They are ghosts that slay. ${ }^{2}$

The leading constitutional challenges to the recent federal health care reform legislation have involved a volatile mixture of powerful political forces pressing for federal court validation. In these suits, elected state officials have aimed to obtain accelerated, abstract review of the legislation's constitutionality. Mere minutes after President Obama signed the Patient Protection and Affordable Care Act into law, Virginia filed one of the first lawsuits, Virginia ex rel. Cuccinelliv. Sebelius, challenging the constitutionality of one of the Act's key provisions. ${ }^{3}$ The first district court decision holding this provision unconstitutional came in Virginia $v$. Sebelius less than nine months later. ${ }^{4}$ In an attempt to "fast-track" the case for immediate Supreme Court review, ${ }^{5}$ Virginia

1. Franchise Tax Bd. v. Constr. Laborers Vacation Trust, 463 U.S. 1, 21-22 (1983).

2. Felix Frankfurter, A Note on Advisory Opinions, 37 HARV. L. REV. 1002, 1008 (1924). I recognize that "slew" is the accepted past tense of the irregular verb "to slay." I have gone back and forth between "slew" and "slayed" in successive drafts of this Article. Bryan Garner continues to classify "slayed" as avoided in careful usage. BRYAN A. GARNER, GARNER'S MODERN AMERICAN USAGE 752-53 (3d ed. 2009). Yet the usage has invaded the Gray Lady at least once. See id. at 753 (quoting usage from the New York Times). And the demise of "slew" is inevitable, even if not imminent. See David Derbyshire, How the Irregular Verb Is Being 'Drived' to Extinction, MAIL ONLINE (Oct. 11, 2007, 1:25 AM), http://www.dailymail.co.uk/news/article-486935/How-irregular-verb-drived-extinction.html (reporting on study conducted at Harvard University including "slew" in a class of infrequently used irregular verbs likely to have evolved into regular verbs within the next 500 years). Those who fault the analysis that follows for being overly wedded to precedent and tied down by the past may take some solace in the avant-garde nature of this essay's titular departure from stodgy old "slew."

3. See Kevin Sack, Judge Voids Key Element of Obama Health Care Law, N.Y. TIMES, Dec. 14, 2010, at A1, available at http://www.nytimes.com/2010/12/14/ health/policy/14health.html ("Mr. Cuccinelli filed the lawsuit minutes after President Obama signed the law on March 23 and has been discussing the case on cable television ever since.").

4. Virginia ex rel. Cuccinelli v. Sebelius, 728 F. Supp. $2 d 768$ (E.D. Va. 2010).

5. See Jennifer Haberkorn \& Sarah Kliff, Health Law Ruling Only the Beginning, POLITICO (Dec. 14, 2010, 7:23 AM), http://www.politico.com/news/stories/1210/46344.html ("Within hours of the ruling, Cuccinelli called for the judicial process to be 'fast-tracked,' essentially bypassing the 4th Circuit Court of Appeals and moving directly to the U.S. Su- 
filed a petition for certiorari before judgment in the Fourth Circuit Court of Appeals. ${ }^{6}$ The Supreme Court denied the petition, but Virginia's lawsuit remained in the lead, as the first to be argued in a court of appeals. Although it ended up being the last case decided in the first wave of mandate challenges to hit the federal appellate courts, the Fourth Circuit's ultimate holding that Virginia lacked standing brought into public view jurisdictional problems facing state challenges to the mandate, problems that had previously escaped wide notice.

Virginia's lawsuit presents on its face a prominent and critically important question of federalism: did Congress exceed the limits of its enumerated legislative powers and thereby trench on a domain reserved by the Constitution to state power? But the lawsuit also presents a previously less recognized but equally important question of separation of powers: is it within the federal judicial power to determine in this lawsuit whether Congress exceeded its legislative powers?

The core claim of this Article is that federal court adjudication of Virginia's lawsuit to enforce limits on federal legislative power exceeds the limits of federal judicial power. Due to limitations that the Supreme Court has placed on federal jurisdiction under the Declaratory Judgment Act in Franchise Tax Board v. Construction Laborers Vacation Trust ${ }^{7}$ and Skelly Oil Co. v. Phillips Petroleum Co., ${ }^{8}$ there is no statutory subject matter jurisdiction over Virginia's claim. In mandating dismissal of Virginia's lawsuit, these cases stop a slide into accelerated, abstract review that is inconsistent with traditional limitations on federal judicial power.

The claim that there is no statutory subject matter jurisdiction in Virginia $v$. Sebelius may seem incredible at first, given that Virginia's complaint seeks relief from a federal law administered by federal officials, on the ground that the federal law violates the Federal Constitution. That may be why nobody thought to address it in the district court. But the claim's soundness becomes apparent once the nature of Virginia's lawsuit is brought into proper focus: Virginia seeks a declaration that its state law is not preempted. The Supreme Court has held, however, that " $\mathrm{t}]$ he situation presented by a State's suit for a declaration

preme Court. Two top Virginia Republicans, Gov. Bob McDonnell and House Minority Whip Eric Cantor, joined in the request."). Although joined by others in the call for expedited review after the ruling, Attorney General Cuccinelli's office had floated the idea of a "fast-track" to the Supreme Court more than a week prior to the ruling. See Jim Nolan, Va. May Seek Quick Care Ruling; Cuccinelli Considers Asking Supreme Court to Hear Case Directly, RICH. TIMES-DISPATCH, Dec. 5, 2010, at A1.

6. See Petition for Writ of Certiorari Before Judgment, Virginia ex rel. Cuccinelli v. Sebelius, 131 S. Ct. 2152 (2011) (No. 10-1014), 2011 WL 465746.

7. 463 U.S. 1 (1983).

8. 339 U.S. 667 (1950). 
of the validity of state law is . . not within the original jurisdiction of the United States district courts."

The jurisdictional issues surrounding Virginia $v$. Sebelius are but the most recent flashpoint of a recurrent phenomenon in American political life-the challenge of legislation in federal court almost immediately after enactment and before it has a chance to take deep root. The federal judiciary's handling of these challenges over time, in turn, has influenced the shape of jurisdictional doctrine, as succeeding generations invoke legal processes and respond to their opponents' perceived abuses of these processes. Thus, while Virginia v. Sebelius is just one case, the implications of the jurisdictional arguments at issue extend far beyond it.

The case squarely presents the question of whether federal jurisdiction can be premised on a state statute designed to obtain a federal declaratory judgment by expressing disagreement with federal law-notwithstanding the established precedents of Franchise Tax Board and Skelly Oil, and the longstanding ban on advisory opinions. To allow federal jurisdiction on this basis would cross an important line and would result in a greater intermixture of politics and law than already exists in constitutional adjudication involving divisive political issues. I argue that this line should not be crossed. But my initial contribution is to demonstrate that this line actually exists.

\section{Virginia's Pursuit of Health CARE FreEdom IN FEDERAL CoURT}

Christmas 2010 arrived twelve days early for Virginia Attorney General Ken Cuccinelli and the top lawyers in his office. Around noon on December 13, Judge Henry Hudson of the United States District Court for the Eastern District of Virginia ruled for Virginia in its case against the mammoth health care reform legislation that President Obama had signed into law a little less than nine months earlier. Judge Hudson held that Congress exceeded the limits of its legislative powers in enacting the Patient Protection and Affordable Care Act. ${ }^{10}$ This decision was the first to hold the Act unconstitutional.

Virginia $v$. Sebelius is a spare, go-it-alone affair in which Virginia is the sole plaintiff. ${ }^{11}$ The single count in the complaint is that one statutory provision-the individual mandate, or minimum essential coverage provision-is unconstitutional. $^{12}$ Although Virginia's claim appears narrow, its object is more ambitious: to take down the entire Act. The instrument for accomplishing this objective is inseverability. This potent doctrine provides that the entire Act must fall if a part of it (like the individual mandate) is unconstitutional, and the

9. Franchise Tax Bd., 463 U.S. at 21-22.

10. Virginia ex rel. Cuccinelli v. Sebelius, 728 F. Supp. 2d 768, 788 (E.D. Va. 2010).

11. See Complaint for Declaratory and Injunctive Relief at 1, Virginia v. Sebelius, 728 F. Supp. 2d 768 (No. 3:10CV188), 2010 WL 1038397.

12. Id. at $5-6$. 
remainder is incapable of functioning independently, or Congress would not have enacted the remainder of the Act without that unconstitutional part. ${ }^{13}$

Virginia's lawsuit aims to vindicate Virginia's Health Care Freedom Act, a mandate-exemption statute that provides that no individual can be required to buy health insurance. ${ }^{14}$ Directly responding to the pending federal individual mandate, both houses of the Virginia legislature passed the Health Care Freedom Act just weeks before President Obama signed the Patient Protection and Affordable Care Act into law. ${ }^{15}$ Answering the criticism that its enactment was just a political stunt (given that state law must give way to federal under the Supremacy Clause), Attorney General Cuccinelli stated in the press that the statute could support Virginia's standing to sue in federal court. ${ }^{16}$ And when Virginia filed its lawsuit just minutes after the Patient Protection and Affordable Care Act became law, the complaint premised its claim on the Health Care Freedom Act.

Virginia seeks a declaratory judgment that its state law remains valid notwithstanding the individual mandate in the federal law, along with injunctive relief prohibiting enforcement of the entire Patient Protection and Affordable Care Act. ${ }^{17}$ Although state law that conflicts with federal law is preempted, an unconstitutional federal statute cannot preempt a valid state statute. In Virginia v. Sebelius, then, Virginia contends that its state statute is valid because the conflicting federal statute is unconstitutional. ${ }^{18}$

13. See Free Enter. Fund v. Pub. Co. Accounting Oversight Bd., $130 \mathrm{~S}$. Ct. 3138 , 3161-62 (2010) (explaining that the challenged statute could remain fully operative as law without unconstitutional restrictions on removal and that the Court therefore "must sustain its remaining provisions ' $[u] n l e s s$ it is evident that the Legislature would not have enacted those provisions ... independently of that which is [invalid]." (alterations in original) (quoting New York v. United States, 505 U.S. 144, 186 (1994)); see also Kevin C. Walsh, Partial Unconstitutionality, 85 N.Y.U. L. REV. 738, 743-44 (2010) (discussing the requirements of severability doctrine).

14. See VA. CODE ANN. $\$ 38.2-3430.1: 1$ (2011). The statute contains certain exceptions not relevant here.

15. See What's Happening at the Capitol Today? Health-Insurance Mandates Rejected, RiCH. TIMES-DiSPATCH, Mar. 11, 2010, at A9 ("The General Assembly told President Barack Obama and Congress yesterday that they cannot make Virginians buy health insurance. Gov. Bob McDonnell said he will sign the legislation. The Associated Press said Virginia is the first state to vote to reject federal mandates.").

16. See Andrew Cain, Cuccinelli: No Insurance Mandate; He Says He'd Defend Virginians from Required Health Care, Rich. TIMES-DISPATCH, Feb. 4, 2010, at A7 ("We'd have a conflict of laws and then the attorney general-me-would be in a position of defending the Virginia law and also attacking the constitutional problems with the proposed health-care bill as it stands.").

17. Complaint for Declaratory and Injunctive Relief, supra note 11, at 6-7.

18. In addition to Virginia, many others also promptly filed suit, including a collection of several states led by Florida, along with a smattering of private individuals and organizations. See Amy Goldstein, Status of Legal Challenges to Obama Health Care Overhaul, WASH. POST (Jan. 31, 2011), available at http://www.washingtonpost.com/wp -srv/special/health-care-overhaul-lawsuits (describing twenty-five lawsuits challenging the constitutionality of the Patient Protection and Affordable Care Act). As these suits have de- 
Although Virginia's Health Care Freedom Act may at first have seemed to provide the Commonwealth with a quick ticket on a solo trip to invalidate the individual mandate, a closer look leads to the opposite conclusion. This analysis reveals that Virginia should be shown the exit from federal court precisely because Virginia seeks to vindicate its state statute in a declaratory judgment action. A straightforward application of established doctrine requires dismissal-not only because Virginia lacks standing (as the Fourth Circuit ultimately concluded), but also because there is no statutory subject matter jurisdiction and Virginia's lawsuit amounts to a request for a forbidden advisory opinion.

\section{NO, VIRGINIA, THERE IS NO FEDERAL JURISDICTION}

The jurisdictional analysis that follows has four parts: the unavailability of parens patriae standing, the absence of statutory subject matter jurisdiction, the absence of jurisdiction under Article III, and an analysis of alternative justiciability theories.

\section{A. No Parens Patriae Standing}

The starting point for analysis of federal jurisdiction over Virginia's lawsuit is that Virginia must either sue on its own behalf or not at all. Massachusetts v. Mellon prevents Virginia from suing on behalf of its own citizens to enjoin the Secretary of Health and Human Services from enforcing the federal individual mandate against those citizens. ${ }^{19}$ The Supreme Court held in Mellon

veloped, the most prominent have been the first two filed by states: Virginia $v$. Sebelius and Florida ex rel. Attorney General v. U.S. Department of Health \& Human Services. Of these two lawsuits, Virginia's initially led the way because it moved at a faster clip. But Florida v. $H H S$ was not far behind. Judge Vinson's eventual holding in that case-that the entire Act was unenforceable because the individual mandate was unconstitutional and inseverable from the remainder of the Act-maintained the continued prominence of that case along with Virginia's. Florida ex rel. Bondi v. U.S. Dep't of Health \& Human Servs., 780 F. Supp. 2d 1256, 1305 (N.D. Fla. 2011). When these cases reached the appellate level, Virginia's began as the most prominent because it was the first to be argued before a court of appeals. But the case faded from the foreground when the Sixth and Eleventh Circuits issued rulings on the constitutionality of the mandate before the Fourth Circuit did. In Thomas More Law Center v. Obama, a divided Sixth Circuit held that private-party plaintiffs failed to show that the individual mandate was facially unconstitutional. See Thomas More Law Ctr. v. Obama, 651 F.3d 529, 540 (6th Cir. 2011), petition for cert. filed, 80 U.S.L.W. 3065 (U.S. July 26, 2011) (No. 11-117). In Florida v. HHS, by contrast, a divided Eleventh Circuit held that the individual mandate was unconstitutional (but severable from the remainder of the Act). Florida ex rel. Attorney Gen. v. U.S. Dep't Health \& Human Servs., 648 F.3d 1235, 1328 (11th Cir. 2011), cert. granted sub nom. Florida v. Dep't of Health \& Human Servs., 80 U.S.L.W. 3199 (U.S. Nov. 14, 2011) (Nos. 11-393, 11-398, 11-400).

19. Massachusetts v. Mellon, 262 U.S. 447 (1923). Massachusetts brought suit against the Secretary of the Treasury challenging a federal statute that appropriated funds to be spent on the improvement of maternal and infant health. Id. at 479 . The challenged act also created a bureau to administer its provisions in cooperation with state agencies. Id. The Court un- 
that "it is no part of [the State's] duty or power to enforce [its citizens'] rights in respect of their relations with the Federal Government." ${ }^{20}$ The Court reasoned that the citizens of a state are also citizens of the United States. To invoke "such protective measures as flow from that status,",21 individuals should look to the federal government directly rather than rely on their states as intermediaries.

Because of Massachusetts $v$. Mellon, Virginia may not proceed against the federal government on behalf of its citizens as parens patriae. ${ }^{22}$ Indeed, this bar is so well-established that Virginia appropriately conceded the point in its briefing. ${ }^{23}$ Eschewing an unsound parens patriae theory, Virginia has relied on sovereign-interest standing. The premise of Virginia's claim of standing to attack the individual mandate in federal court was the asserted need to defend the Virginia Health Care Freedom Act. As mentioned above, Virginia's Attorney General identified an anticipated standing-conferring function of the Virginia statute as one reason to pass it, and this position prevailed in the district court. ${ }^{24}$ Yet neither the parties nor the district court nor the Fourth Circuit examined whether Congress has vested the federal courts with statutory subject matter jurisdiction to adjudicate a state's claim of bare conflict between state and federal law in these circumstances. As the analysis in the next Part reveals, however, it has not.

\section{B. No Statutory Subject Matter Jurisdiction}

Virginia's complaint asserts that the district court has jurisdiction over the case under the general grant of federal question jurisdiction, 28 U.S.C. $\S 1331$, and the Federal Declaratory Judgment Act, 28 U.S.C. $\$ 2201 .^{25}$ The difficulty with direct reliance on $\S 1331$ in a suit seeking declaratory relief is that the $\mathrm{Su}$ -

derstood Massachusetts's claim to be that its "rights and powers as a sovereign State and the rights of its citizens have been invaded and usurped." Id.

20. Id. at $485-86$.

21. Id. at 486 .

22. This bar on parens patriae standing is probably not constitutionally compelled, but rather is best understood as a prudential limit that can be overcome by congressional action. See Md. People's Counsel v. Fed. Energy Regulatory Comm'n, 760 F.2d 318, 321-22 (D.C. Cir. 1985) (Scalia, J.) (holding that Massachusetts $v$. Mellon set forth a prudential standing requirement rather than a "core component" of constitutional standing doctrine).

23. Plaintiff's Memorandum in Opposition to Motion to Dismiss at 12, Virginia ex rel. Cuccinelli v. Sebelius, 702 F. Supp. 2d 598 (E.D. Va. 2010) (No. 3:10CV188), 2010 WL 2417176 " "Virginia recognizes that Massachusetts $v$. Mellon stands for the proposition that States cannot sue the federal government under parens patriae principles because their citizens are also citizens of the United States.").

24. Virginia v. Sebelius, 702 F. Supp. 2d at 605-07.

25. Complaint for Declaratory and Injunctive Relief, supra note 11 , at 3 (citing 28 U.S.C. $\S 1331$ (2006), and mistakenly citing 28 U.S.C. $\S 2001$ (2006) instead of 28 U.S.C. $\S 2201(2006))$. 
preme Court has interpreted $\S 2201$ as placing limits on jurisdiction under $\S 1331$ - limits that require dismissal of Virginia v. Sebelius. ${ }^{26}$

The limit most directly applicable to Virginia $v$. Sebelius is the one the Supreme Court imposed in Franchise Tax Board v. Construction Laborers Vacation Trust. ${ }^{27}$ Franchise Tax Board was a declaratory judgment action filed by a state agency in state court seeking a declaration that its tax law was not preempted by ERISA. ${ }^{28}$ The Court had previously interpreted $\S 2201$ to include certain limits on federal jurisdiction over declaratory judgment actions. ${ }^{29}$ To avoid the use of state declaratory judgment actions, removed into federal court, as a way of circumventing limitations previously imposed on federal declaratory judgment actions, the Court determined that those limitations would apply whenever a litigant sought to bring a state declaratory judgment action into federal court. ${ }^{30}$ Moreover, because removal jurisdiction is coextensive with original jurisdiction, the holding of Franchise Tax Board regarding the reach of $\S 2201$ applies not only to cases removed into federal court, but also to those filed there originally. ${ }^{31}$

Most importantly for present purposes, however, the Supreme Court in Franchise Tax Board did more than simply extend prior limitations on federal declaratory judgments to state declaratory judgments. It imposed a new limitation on jurisdiction that applies when states seek declaratory relief under $\S 2201$. The Court held that "[t]he situation presented by a State's suit for a declaration of the validity of state law is ... not within the original jurisdiction of the United States district courts." ${ }^{32}$ The Court contemplated that a state could instead enforce its state statute in state court, the state court defendant could then invoke the federal defense of preemption, and the state court would

26. See Franchise Tax Bd. v. Constr. Laborers Vacation Trust, 463 U.S. 1, 18 (1983) ("Having interpreted the Declaratory Judgment Act of 1934 to include certain limitations on the jurisdiction of federal district courts to entertain declaratory judgment suits, we should be extremely hesitant to interpret the Judiciary Act of 1875 and its 1887 amendments [i.e., the general grant of federal question jurisdiction] in a way that renders the limitations in the later statute nugatory.").

27. Id.

28. Id. at 5-7.

29. Id. at 18. The limits referred to in the text are those set forth in Skelly Oil, discussed below. See infra text accompanying notes 40-49.

30. See Franchise Tax Bd., 463 U.S. at 18-19 ("[W]e hold that under the jurisdictional statutes as they now stand federal courts do not have original jurisdiction, nor do they acquire jurisdiction on removal, when a federal question is presented by a complaint for a state declaratory judgment, but Skelly Oil would bar jurisdiction if the plaintiff had sought a federal declaratory judgment." (footnote omitted)).

31. See id. at 21-22.

32. Id. 
decide that question (with the potential for ultimate review in the United States Supreme Court via a petition for a writ of certiorari). ${ }^{33}$

This holding squarely forecloses federal jurisdiction in Virginia $v$. Sebelius, in which Virginia asks the court "to declare that $\S 1501$ of PPACA is unconstitutional because the individual mandate exceeds the enumerated powers conferred upon Congress," and also to "declare that [Virginia's Health Care Freedom Act] is a valid exercise of state power.",34 As the district court noted (in the course of analyzing a different point), the raison d'être of Virginia's federal declaratory judgment lawsuit is to determine the validity of Virginia law ${ }^{35}$ which is why Franchise Tax Board requires dismissal.

One response to this line of argument may be to treat Franchise Tax Board as a sort of abstention decision. In Franchise Tax Board, the states' ability to litigate their non-preemption claims against the declaratory judgment defendants in state court was foremost among the "good reasons why the federal courts should not entertain suits by the States to declare the validity of their regulations despite possibly conflicting federal law." ${ }^{36}$ The Franchise Tax Board's inability to be a declaratory judgment plaintiff in a federal forum left the Board with the ability to prosecute its action in a state court and to have the issue of preemption litigated there.

By contrast, Virginia has not contended that it could bring a state court enforcement action against the federal government under its Health Care Freedom Act. The district court held that Virginia's law was "declaratory" in nature,

33. See id. at 21 ("States ... have a variety of means by which they can enforce their own laws in their own courts, and they do not suffer if the pre-emption questions such enforcement may raise are tested there.").

34. Complaint for Declaratory and Injunctive Relief, supra note 11, at 6. Virginia also asks for "such further and additional relief as the ends of justice may require including an injunction against the enforcement of $\S 1501$ in particular and PPACA as a whole." Id. at 67. As this wording reveals, however, the request for an injunction is ancillary to the request for declaratory relief. A court cannot reach the "further and additional" remedy of an injunction without making the declaration of state law validity that Franchise Tax Board holds to be beyond the jurisdiction granted by Congress in $\S 1331$. Consequently, Virginia's claim for the "further and additional relief" of an injunction, $i d$. at 7 , cannot be independently salvaged from its extrajurisdictional claim for declaratory relief. Furthermore, as explained in more detail below, the federal court lacks Article III jurisdiction to issue the requested injunction.

35. Virginia ex rel. Cuccinelli v. Sebelius, 702 F. Supp. 2d 598, 605 (E.D. Va. 2010) (explaining that the "primary articulated objective" of the lawsuit is "to defend the Virginia Health Care Freedom Act from the conflicting effect of an allegedly unconstitutional federal law").

36. Franchise Tax Bd., 463 U.S. at 21 . The Court determined that "[s]tates are not significantly prejudiced by an inability to come to federal court for a declaratory judgment in advance of a possible injunctive suit by a person subject to federal regulation." $l d$. The reason for this lack of significant prejudice is that states "have a variety of means by which they can enforce their own laws in their own courts, and they do not suffer if the pre-emption questions such enforcement may raise are tested there." Id. 
meaning that it could not be directly enforced against anybody. ${ }^{37}$ On this understanding of the Health Care Freedom Act, Virginia could not bring any enforcement action, because the Act does not impose a prohibition whose violation would be actionable; it instead supplies an immunity against being obligated to obtain or maintain health insurance. In responding to different jurisdictional objections advanced by the federal government and amici, however, Virginia argued in its appeal that the Attorney General of Virginia could bring certain actions for injunctive relief to enforce the Health Care Freedom Act. More specifically, Virginia argued that its Attorney General could bring an action for injunctive relief against a locality that required the purchase of insurance, or against an employer that required employees to purchase insurance as a condition of employment. ${ }^{38}$ Even if the Attorney General could bring such actions, however, state court suits against local governments or private employers would not raise the same preemption issue raised by the declaratory judgment action against the federal government. As the federal government has noted, nothing in the Patient Protection and Affordable Care Act prohibits states "from barring local governments and private employers from requiring insurance." 39 In the hypothetical enforcement actions identified by Virginia, then, federal law would not preempt the operation of state law.

Admittedly, the absence of a Virginia state court enforcement action like that contemplated by the Supreme Court in Franchise Tax Board is a distinguishing feature of that case. But the distinction provides even more of a reason to apply the rule of Franchise Tax Board and dismiss Virginia v. Sebelius. The precedent forecloses statutory subject matter jurisdiction over a state's declaratory judgment action to determine the validity of a law that a state actually could enforce in state court against the declaratory judgment defendant. It would make little sense to read Franchise Tax Board as allowing for jurisdiction over a state's declaratory judgment action to determine the validity of a state law that cannot be enforced against the federal declaratory judgment defendants.

These considerations point to a further flaw with Virginia's lawsuit. Even if one were to distinguish Franchise Tax Board as embodying nothing more than some sort of abstention principle (notwithstanding the Court's broader formulation of its holding), Virginia's suit would still need to satisfy the test of Skelly Oil.

It cannot. In Skelly Oil, Justice Frankfurter wrote in his opinion for the Court that the Declaratory Judgment Act "enlarged the range of remedies avail-

37. Virginia v. Sebelius, 702 F. Supp. $2 \mathrm{~d}$ at 605.

38. Appellee's Opening and Response Brief at 14-15, Virginia ex rel. Cuccinelli v. Sebelius, 656 F.3d 253 (4th Cir. 2011) (Nos. 11-1057, 11-1058), 2011 WL 1115016.

39. Response/Reply Brief for Appellant at 8, Virginia v. Sebelius, 656 F.3d 253 (Nos. 11-1057, 11-1058), 2011 WL 1338077. 
able in the federal courts but did not extend their jurisdiction." 40 A declaratory judgment could provide a remedy, but only in cases in which the underlying dispute would have been within federal jurisdiction. As applied in later cases, the Skelly Oil approach to $\S 2201$ allows for federal jurisdiction over only those declaratory judgment actions in which either the declaratory judgment plaintiff or the declaratory judgment defendant could have brought a nondeclaratory action against the other party. ${ }^{41}$ As matters now stand, then, federal jurisdiction over a declaratory judgment action brought under $\S 2201$ "depends on the answer to a hypothetical question: had the Declaratory Judgment Act not been enacted, would there have been a nondeclaratory action (i) concerning the same issue, (ii) between the same parties, (iii) that itself would have been within the federal courts' subject matter jurisdiction?"42

Virginia cannot satisfy the Skelly Oil test because it possesses no right to nondeclaratory relief against enforcement of the individual mandate by the Secretary of Health and Human Services. ${ }^{43}$ Virginia may not seek an injunction prohibiting the Secretary's enforcement of the individual mandate against its citizens; that would be a parens patriae action forbidden by Massachusetts $v$. Mellon. Nor may Virginia seek an injunction prohibiting the Secretary's enforcement of the individual mandate against Virginia; the individual mandate, by its terms, is not enforceable against Virginia-only against individuals. ${ }^{44}$

40. Skelly Oil Co. v. Phillips Petroleum Co., 339 U.S. 667, 671 (1950) (emphasis added); see also id. at 671-72 ("The Declaratory Judgment Act allowed relief to be given by way of recognizing the plaintiff's right even though no immediate enforcement of it was asked. But the requirements of jurisdiction ... were not impliedly repealed or modified.").

41. Richard H. Fallon, JR. ET al., Hart \& WeChSler's the Federal COURTS and THE FEDERAL SYSTEM 805 (6th ed. 2009).

42. Id. at 804 .

43. The discussion that follows addresses injunctive relief only, not damages. Virginia would not be entitled to seek damages unless one fancifully imagines that it would be appropriate for the Supreme Court to create some sort of a Bivens claim based on the Tenth Amendment. See Bivens v. Six Unknown Named Agents of Fed. Bureau of Narcotics, 403 U.S. 388 (1971).

44. See Patient Protection and Affordable Care Act $\S 1501,26$ U.S.C. $\S 5000$ A (Supp. IV 2011) (imposing minimum insurance coverage requirement on "applicable individuals"); Virginia ex rel. Cuccinelli v. Sebelius, 702 F. Supp. 2d 598, 605 (E.D. Va. 2010) (stating that Virginia is "a sovereign entity not required to purchase insurance under . . . the Patient Protection and Affordable Care Act"); Plaintiff's Memorandum in Opposition to Motion to Dismiss, supra note 23, at 18-19 ("As Secretary Sebelius concedes, Virginia will not be required to pay the penalty for failure to meet the Individual Mandate. ... Virginia will incur no direct financial liability under the challenged penalty provision ...."); Memorandum in Support of Defendant's Motion to Dismiss at 1, Virginia v. Sebelius, 702 F. Supp. 2d 598 (3:10CV188), $2010 \mathrm{WL} 2315702$ (" $[\mathrm{T}]$ he only provision Virginia challenges in this litigation-Section 1501 of the Patient Protection and Affordable Care Act ...., which requires individuals either to obtain a minimum level of health insurance or to pay a penalty if they do not-will impose no obligations on the Commonwealth, even after the law takes effect some four years from now. The provision applies only to individuals, not the state government."); id. at 13 (stating that the individual mandate provision "does not impose any obligations whatsoever on Virginia as a state"). 
Injunctions do not run against statutes, but against actors. "If a case for preventive relief be presented the court enjoins, in effect, not the execution of the statute, but the acts of the official, the statute notwithstanding., ${ }^{, 5}$ As the wording of its complaint reveals, Virginia accepts this basic principle. ${ }^{46}$ But once this principle is applied to the individual mandate, Virginia's inability to seek injunctive relief prohibiting the secretary's enforcement of that law against Virginia is clear. The reason is simple: If the secretary can take no action against Virginia pursuant to the individual mandate, there is no basis for a federal court to enjoin "the acts of the official, the statute notwithstanding." ${ }^{.47}$ And, as already mentioned, the individual mandate does not apply to Virginia-just to individuals.

Nor can the Skelly Oil test be satisfied under these circumstances by hypothesizing an action for declaratory and injunctive relief by the federal government against Virginia. There are certainly circumstances in which the federal government can bring such an action against a state. In a recent lawsuit against Arizona, for example, the federal government sought to enjoin the enforcement of a state law requiring state officers to enforce federal immigration law. ${ }^{48}$ But Virginia's Health Care Freedom Act poses no similar specter of state interference with the day-to-day operations of the federal government. Unlike Arizona's law, Virginia's law does not authorize state officers to interfere with federal operations. As mentioned above, the only two types of actions for injunctive relief that Virginia has asserted it can bring to enforce the Health Care Freedom Act-against localities or against private employers who make the possession of insurance a condition of employment-do not interfere with the federal requirement to possess health insurance or pay a penalty. Consequently, there is no basis for the federal court to seek to enjoin "the acts of the official, the [state] statute notwithstanding. ${ }^{, 49}$

The Fourth Circuit did not address statutory subject matter jurisdiction in Virginia v. Sebelius; it did not need to given its conclusion that Virginia lacked standing. The absence of explicit discussion of this issue should not be taken as a signal that the statutory subject matter jurisdiction defects have no practical relevance, either for Virginia v. Sebelius or for cases like it in the future. Suppose Virginia were able to show that the Fourth Circuit's standing analysis is incorrect (although I doubt this can be done). The absence of statutory jurisdiction would remain an obstacle to proceeding in Virginia v. Sebelius or in other cases like it. More importantly, Franchise Tax Board would also remain an ob-

45. Massachusetts v. Mellon, 262 U.S. 447, 488 (1923).

46. Complaint for Declaratory and Injunctive Relief, supra note 11, at 7 (requesting "an injunction against the enforcement of $\S 1501$ in particular and PPACA as a whole" (emphasis added)).

47. Mellon, 262 U.S. at 488.

48. Complaint at 1, United States v. Arizona, 703 F. Supp. 2d 980 (D. Ariz. 2010) (No. 2:10-CV-1413), 2010 WL 2653363.

49. Mellon, 262 U.S. at 488. 
stacle to any state's effort to obtain federal jurisdiction by enacting a statute that - unlike Virginia's - could actually be enforced in a way that conflicts with federal law. California's law in Franchise Tax Board was a law of this type-a tax law that the State wanted to use to collect revenue-and yet the Supreme Court held that the State's request for a declaratory judgment of nonpreemption was outside of the limited jurisdiction granted to federal courts by Congress.

\section{No Article III Case of Actual Controversy}

The analysis up to this point has explained why-once Virginia is confined to suing on its own behalf rather than as representative of its citizens in a parens patriae capacity - there is no statutory subject matter jurisdiction over Virginia's lawsuit. While the holdings of Franchise Tax Board and Skelly Oil each lead to this conclusion, a complete jurisdictional analysis does not stop at this point. A more fundamental jurisdictional defect with Virginia's lawsuit is that it is outside of the limited jurisdiction authorized by Article III.

The language of the Declaratory Judgment Act provides a clean path of entry into an analysis of the ways in which Virginia v. Sebelius runs afoul of Article III limitations on federal jurisdiction. To ensure that the Declaratory Judgment Act would not enable courts to exceed the bounds of Article III, Congress made the remedy of declaratory relief available only in "a case of actual controversy" 50 - language that is to be interpreted as coextensive with the case or controversy limitation of Article III. ${ }^{51}$ For there to be an "actual controversy" cognizable under the Declaratory Judgment Act and Article III, a dispute must be "definite and concrete, touching the legal relations of parties having adverse legal interests." 52 The dispute must "admit[] of specific relief through a decree of a conclusive character, as distinguished from an opinion advising what the law would be upon a hypothetical state of facts." 53

The fundamental problem in Virginia $v$. Sebelius is that both the individual mandate in federal law and the mandate immunity in state law relate to the legal obligations of individuals, not states. In essence, Virginia seeks a ruling about what law would apply if and when there is an actual controversy between the federal government and a Virginia resident over the individual mandate.

50. 28 U.S.C. $\S 2201$ (2006).

51. See MedImmune, Inc. v. Genentech, Inc., 549 U.S. 118, 127 (2007) ("[T]he phrase 'case of actual controversy' in the [Declaratory Judgment] Act refers to the types of 'Cases' and 'Controversies' that are justiciable under Article III.").

52. Aetna Life Ins. Co. v. Haworth, 300 U.S. 227, 240-41 (1937) (citations omitted); see also id. at 239-40 ("The Declaratory Judgment Act of 1934, in its limitation to "cases of actual controversy,' manifestly has regard to the constitutional provision and is operative only in respect to controversies which are such in the constitutional sense.").

53. Id. at 241; see also MedImmune, 549 U.S. at 127 (adopting the foregoing descriptions of the meaning of "actual controversy"). 
The Supreme Court held in Muskrat v. United States that a bare request for a judicial determination of the constitutional validity of an act of Congress is not itself a "case" or "controversy." 54 Muskrat involved lawsuits brought by certain Cherokee Indians who had an interest in property granted them by Congress in $1902 .{ }^{55}$ Federal legislation enacted in 1904 and 1906 purported to dilute their property interests. ${ }^{56}$ They contended, however, that this later legislation was unconstitutional..$^{57}$ Congress enacted a statute authorizing claimants under the 1902 statute to file suit against the United States in the Court of Claims, with appellate jurisdiction in the Supreme Court, to determine the constitutional validity of the 1904 and 1906 statutes. ${ }^{58}$ The Supreme Court held that suits filed against the United States pursuant to this statutory authorization did not fall within the judicial power conferred in Article III. ${ }^{59}$ The Court explained that the "judicial power" granted in Article III "is the power of a court to decide and pronounce a judgment and carry it into effect between persons and parties who bring a case before it for decision." ${ }^{60}$ Although the United States was a defendant, the United States had "no interest adverse to the claimants," who sought not to assert a property right against the government or to demand compensation, but rather to determine the constitutional validity of legislation. $^{61}$

The Court's critical reasoning in Muskrat came in its analysis of the legal effect of the judgment requested in the case. The Court observed that the only judgment required in the proceeding "is to settle the doubtful character of the legislation in question." 62 That judgment would not bind "private parties, when actual litigation brings to the court the question of the constitutionality of such legislation." ${ }^{63}$ The Court continued: "In a legal sense the judgment could not be executed, and amounts in fact to no more than an expression of opinion upon the validity of the acts in question." 64

The judgment requested in Virginia $v$. Sebelius possesses the same defect. The district court's determination that the individual mandate is unconstitutional had no binding legal effect on anyone subject to the individual mandate, whether in Virginia or elsewhere. The general rule (with exceptions not rele-

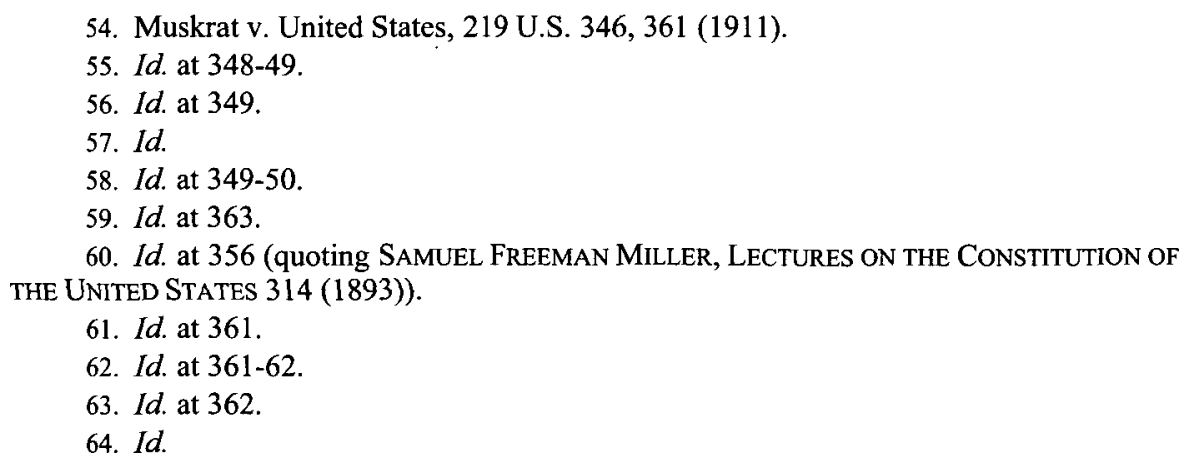


vant here) is that a judgment binds only the parties. ${ }^{65}$ That binding effect does not amount to much in a case like Virginia $v$. Sebelius because the sole party challenging the individual mandate is a party against whom it could not be enforced. An injunction against enforcement of the mandate against nonpartiesVirginia residents-would run into the Mellon bar on states suing the federal government to protect their residents from the operation of federal law.

Nor would the district court's judgment in Virginia $v$. Sebelius have any binding effect in a later case. A private individual in a later suit could not wield the decision against the federal government through the doctrine of nonmutual offensive issue preclusion, because that doctrine cannot be used against the federal government. ${ }^{66}$ Moreover, the district court's decision set no precedent binding in later cases, because "federal district judges, sitting as sole adjudicators, lack authority to render precedential decisions binding other judges, even members of the same court." ${ }^{.67}$ Simply put, Virginia's lawsuit does not present a "case of actual controversy" under the Declaratory Judgment Act or Article III because it does not "admi[ $t$ ] of specific relief through a decree of a conclusive character, as distinguished from an opinion advising what the law would be upon a hypothetical state of facts." 68

Presenting a different rationale for the same conclusion that Virginia $v$. Sebelius is outside Article III, the federal government-supported on this point by an array of academic amici on appeal-argued that Virginia lacked standing. Stripped to its essentials, the basic argument is that states cannot circumvent the Mellon bar on parens patriae standing by passing a state law that disagrees with federal law; the abstract clash between federal and state law does not constitute a legally cognizable injury. ${ }^{69}$

Nothing in the foregoing advisory opinion analysis contradicts the nostanding position put forward by the federal government and academic amici, which I believe to be sound. ${ }^{70}$ In a trio of cases decided in the $1920 \mathrm{~s}$, before modern standing doctrine had assumed the shape it now has, the Supreme Court held to be outside of Article III various state claims that a particular pro-

65. See, e.g., Taylor v. Sturgell, 553 U.S. 880, 893 (2008) ("[W]e have often repeated the general rule that 'one is not bound by a judgment in personam in a litigation in which he is not designated as a party or to which he has not been made a party by service of process."” (quoting Hansbury v. Lee, 311 U.S. 32, 40 (1940))).

66. See United States v. Mendoza, 464 U.S. 154, 162-63 (1984).

67. Am. Elec. Power Co. v. Connecticut, 131 S. Ct. 2527, 2540 (2011).

68. Medlmmune, Inc. v. Genentech, Inc., 549 U.S. 118, 127 (2007) (alteration in original) (quoting Aetna Life Ins. Co. v. Haworth, 300 U.S. 227, 241 (1937)).

69. Brief for Appellant at 25, Virginia ex rel. Cuccinelli v. Sebelius, 656 F.3d 253 (4th Cir. 2011) (Nos. 11-1057, 11-1058), 2011 WL 686279; see also Brief of Amici Curiae Professors of Federal Jurisdiction in Support of Appellant at 6, Virginia v. Sebelius, 656 F.3d 253 (Nos. 11-1057, 11-1058), 2011 WL 792210.

70. For a more critical assessment of the government's standing arguments, see Katherine Mims Crocker, Note, Securing Sovereign State Standing, 97 VA. L. REV. 2051 (2011). 
vision of federal law is beyond the federal government's authority. ${ }^{71}$ Those decisions built on Georgia v. Stanton, in which the Court dismissed a state's bill in equity for lack of jurisdiction because the rights at issue were "merely political rights, which do not belong to the jurisdiction of a court, either in law or equity."72

In my view, understanding the jurisdictional defect in advisory-opinion terms rather than in lack-of-cognizable-injury terms better captures the jurisdictional problem with Virginia $v$. Sebelius. The problem with the asserted injury is that it is entirely abstract when considered apart from the application of the mandate to Virginia residents. The advisory opinion framework brings this feature of the lawsuit into sharp relief.

Moving from the academic's to the advocate's point of view, however, the standing framework admittedly has the virtue of being more familiar to the judiciary. Yet familiarity with standing doctrine in general does not guarantee correct analysis of the state standing issues peculiar to that corner of standing doctrine. These distinctive doctrinal twists render standing doctrine-itself notoriously murky - even more susceptible to incorrect application with respect to questions of state standing.

The district court concluded that Virginia possessed standing because it alleged a sovereign injury from the clash between federal and state law. ${ }^{73}$ The court relied principally on a Tenth Circuit decision stating that "[f]ederal regulatory action that preempts state law creates a sufficient injury-in-fact to satisfy this prong" of a standing analysis. ${ }^{74}$ Virginia's briefing also identified additional cases from other circuits in which preemption formed part of the injury-

71. In Texas v. Interstate Commerce Commission, the Court described the question of whether matters addressed in federal legislation challenged by Texas "fall within the field wherein Congress may speak with constitutional authority, or within the field reserved to the several States" as "an abstract question of legislative power." 258 U.S. 158, 162 (1922). Similarly, in Massachusetts $v$. Mellon, the Supreme Court not only held that Massachusetts lacked parens patriae standing against the federal government, but also held that the State could not sue the federal government on its own behalf. 262 U.S. 447, 484-85 (1923). The Court contrasted "rights of person or property" within the Court's jurisdiction, with "abstract questions of political power, of sovereignty, of government," outside of the Court's jurisdiction. Id. Finally, in New Jersey v. Sargent, the Court dismissed the State's bill in equity upon concluding that "its real purpose is to obtain a judicial declaration that, in making certain parts of the Federal Water Power Act ... Congress exceeded its own authority and encroached on that of the state." 269 U.S. 328, 334 (1926). New Jersey's bill in equity, said the Court, "does not show that any right of the State, which in itself is an appropriate subject of judicial cognizance, is being, or about to be, affected prejudicially by the application or enforcement of the Act." Id.

72. 73 U.S. (6 Wall.) 50, 76 (1868). 2010).

73. Virginia ex rel. Cuccinelli v. Sebelius, 702 F. Supp. 2d 598, 606-07 (E.D. Va.

74. Id. at 607 (quoting Wyoming ex rel. Crank v. United States, 539 F.3d 1236, 1242 (10th Cir. 2008)) (internal quotation marks omitted). 
in-fact to provide standing. ${ }^{75}$ In none of these cases, however, was the clash between federal and state law entirely abstract, as it is in Virginia v. Sebelius.

Certainly, a fight against federal preemption can amount to a justiciable case in some circumstances. But the circuit court decisions relied upon by the district court and Virginia were not pure declaratory judgment actions leading to no binding legal effect. The states in those cases relied on statutory authorizations to sue that were defined in such a way that the states' challenges involved the legality of a particular action by an agency of the federal government that had interfered with some particular activity of the states themselves (such as issuing permits, promulgating regulations, or undertaking enforcement actions). ${ }^{76}$ Each challenge involved an adverse officer or agency whose action could be declared void or enjoined to redress the injury that the federal government's particular challenged action had inflicted on the state. ${ }^{77}$ In Virginia v. Sebelius, by contrast, Virginia had no statutory basis for judicial review apart from the Declaratory Judgment Act; the Commonwealth complained of no particular agency action that could be directed against it; and the resulting district court judgment about the constitutionality of the mandate had no binding legal effect on anybody actually subject to the individual mandate.

The Fourth Circuit's opinion ordering dismissal of Virginia v. Sebelius for lack of jurisdiction framed the jurisdictional defect as the absence of a judicially cognizable injury sufficient to provide Virginia with standing. ${ }^{78}$ More particularly, the court concluded that "Virginia lacks standing to challenge the individual mandate because the mandate threatens no interest in the 'enforceability' of the [Virginia Health Care Freedom Act]."79 The Fourth Circuit's determination that Virginia lacks standing leads to the same outcome as

75. Plaintiff's Memorandum in Opposition to Motion to Dismiss, supra note 23, at 16 (citing Crank, 539 F.3d at 1242; Tex. Office of Pub. Util. Counsel v. FCC, 183 F.3d 393, 449 (5th Cir. 1999); Alaska v. U.S. Dep't of Transp., 868 F.2d 441, 443 n.1 (D.C. Cir. 1989); Ohio ex rel. Celebrezze v. U.S. Dep't of Transp., 766 F.2d 228, 232-33 (6th Cir. 1985)).

76. See Crank, 539 F.3d at 1242-44 \& n.6 (engaging in judicial review of an ATF determination pursuant to the Administrative Procedure Act (APA) section 704, which states that "[a]gency action made reviewable by statute and final agency action for which there is no other adequate remedy in a court are subject to judicial review" (quoting 5 U.S.C. $§ 704$ (2006)); Tex. Office of Pub. Util. Counsel, $183 \mathrm{~F} .3 \mathrm{~d}$ at 405 (engaging in judicial review of final orders of the Federal Communications Commission pursuant to 28 U.S.C. $\$ \S 2342$, 2344 (2006), and the Communications Act, 47 U.S.C. $\$ 402$ (a) (2006)); Alaska, 868 F.2d at 444-45 (engaging in judicial review of orders of the Department of Transportation pursuant to the APA and the Aviation Act, which includes "a body politic" or a "representative thereof" within the class of persons entitled to judicial review); Celebrezze, 766 F.2d at 232-33 (engaging in judicial review of a regulation and interpretive rule pursuant to the APA and the Hazardous Materials Transportation Act).

77. See cases cited supra note 76.

78. Virginia ex rel. Cuccinelli v. Sebelius, 656 F.3d 253, 266 (4th Cir. 2011), petition for cert. filed, 80 U.S.L.W. 3221 (U.S. Sep. 30, 2011) (No. 11-420).

79. Id. at 269 . 
the foregoing analyses of statutory subject matter jurisdiction and advisory opinion doctrine. But those analyses also suggest reason for caution in identifying the justiciability problem as a lack of cognizable injury alone.

The reason for caution is this: A state's claim could satisfy the Fourth Circuit's requirement for a judicially cognizable sovereign injury and yet still not amount to an Article III case or controversy or fall within the limited statutory jurisdiction of the federal courts. Suppose that state law were to prohibit private employers from requiring insurance as a condition of employment, and federal law were simultaneously to require private employers to provide insurance as a condition of employment. This clash between federal and state law would threaten the enforceability of a state law, and thereby satisfy what appears to be the Fourth Circuit's test for a judicially cognizable sovereign injury. It would not necessarily follow from this configuration of state and federal law that the state would have a justiciable declaratory judgment claim against the federal government in an Article III court. Such a claim might be best understood as seeking an advisory opinion about which law would govern if and when either the state or the federal government sought to enforce its prohibition or requirement against a covered employer. The point of making this observation is not to criticize the Fourth Circuit's analysis on its own terms, but rather to contend that a focus on standing analysis alone runs the danger of missing other jurisdictional defects that do not fit neatly into the three-part injury/causation/redressability framework of modern standing doctrine.

\section{Alternative Justiciability Theories?}

The analysis up to this point has examined the arguments aired in Virginia $v$. Sebelius. The result of that analysis is that there is neither statutory subject matter jurisdiction nor Article III jurisdiction over Virginia v. Sebelius. That result is a good one, as the arguments in the final Part below aim to establish. But before getting to those arguments about the normative desirability of the result, it remains necessary to consider any other jurisdictional arguments that might be advanced to bring a suit like Virginia $v$. Sebelius into federal court. If alternative avenues to adjudication of a state challenge to federal law allow an easy way around the doctrines applied above, then the normative desirability of the appropriate outcome in Virginia $v$. Sebelius would be ultimately beside the point. Accordingly, this Subpart addresses the jurisdictional arguments advanced in Florida ex rel. Attorney General v. United States Department of Health \& Human Services, ${ }^{80}$ a more sprawling case that has spawned additional theories for the justiciability of states' challenges to the individual mandate.

80. 648 F.3d 1235 (11th Cir. 2011), cert. granted sub nom. Florida v. Dep't of Health \& Human Servs., 80 U.S.L.W. 3199 (U.S. Nov. 14, 2011) (Nos. 11-393, 11-398, 11-400). 
Florida v. HHS is a lawsuit filed on behalf of several states the same day as Virginia $v$. Sebelius. ${ }^{81}$ After the initial filing, the case grew to include as plaintiffs twenty-six states or state officials acting on behalf of the people of a state, two private individuals, and the National Federation of Independent Businesses. ${ }^{82}$ At the motion to dismiss stage, Judge Vinson in Florida v. HHS did not address state standing to challenge the individual mandate. Instead, Judge Vinson decided only that the private individuals in that case had standing to challenge the individual mandate, remaining silent on the issue of state standing to challenge this provision. ${ }^{83}$ When the case proceeded to summary judgment, however, Judge Vinson held that two states, Idaho and Utah, had standing to challenge the individual mandate because they had "passed legislation seeking to protect their citizens from forced compliance with the individual mandate." 84 In so holding, Judge Vinson relied directly on the analysis in Virginia v. Sebelius. $^{85}$

The reliance on two states' antimandate laws was flawed for reasons described above with respect to Virginia's law. Even if correct, however, the jurisdictional analysis in Florida $v$. HHS relying on the existence of antimandate laws would be insufficient to support jurisdiction over the challenges brought by states lacking antimandate laws. Accordingly, the states advanced two additional jurisdictional theories that a complete analysis should address.

The states' lead theory is one of indirect injury through Medicaid enrollment. The states have argued that they will be injured because they will incur costs when some individuals choose to comply with the individual mandate by enrolling in a state Medicaid program. ${ }^{86}$ This allegation of indirect injury is insufficient as a matter of law. In Florida $v$. Mellon, the State of Florida sought to challenge a federal tax on the ground that the federal tax would "have the result of inducing potential tax-payers to withdraw property from the state, thereby diminishing the subjects upon which the state power of taxation may operate." $" 87$ The Court held that the State could not go forward with the suit because the State was not in immediate danger of sustaining "any direct injury as the

81. Complaint, Florida ex rel. Bondi v. U.S. Dep't of Health \& Human Servs., 780 F. Supp. 2d 1307 (N.D. Fla. 2011) (No. 3:10-cv-91-RV/EMT), 2010 WL 1038209.

82. Second Amended Complaint, Florida v. HHS, 780 F. Supp. 2d 1307 (No. 3:10-cv91-RV/EMT), 2011 WL 247074.

83. Florida ex rel. McCollum v. U.S. Dep't of Health \& Human Servs., 716 F. Supp. 2d 1120, 1144-47 (N.D. Fla. 2010).

84. Florida v. HHS, 780 F. Supp. 2d at 1272. here.").

85. See id. ("I agree with Judge Hudson's thoughtful analysis of the issue and adopt it

86. Opening/Response Brief of Appellee/Cross-Appellant States at 67-68, Florida ex rel. Attorney Gen. v. U.S. Dep't of Health \& Human Servs., 648 F.3d 1235 (11th Cir. 2011) (Nos. 11-11021, 11-11067), 2011 WL 1944107.

87. Florida v. Mellon, 273 U.S. 12, 17-18 (1927). 
result of the enforcement of the act in question., ${ }^{, 88}$ In short, the Court drew a line between direct and indirect injury, and held that it lacked jurisdiction because the claimed injury to the state fisc arising by virtue of the actions of private citizens in response to the federal law was indirect. ${ }^{89}$

A line between direct and indirect injury may be open to criticism, but it is administrable enough to foreclose the claimed injury to states resulting from individuals' compliance with the minimum essential coverage provision. Unless there is some line, moreover, the bar on parens patriae standing against the federal government would disappear. As Ann Woolhandler and Michael Collins have explained, the line between direct and indirect injuries can be useful as a way of focusing attention on whether a state plaintiff is advancing legally protected interests that deserve a federal judicial forum. ${ }^{90}$

It is also worth noting that the states' claimed injury from enforcement of the mandate against state residents is not only indirect, but also derivative of the rights of state residents. If Congress exceeded its authority in enacting the individual mandate, then the individuals against whom the federal government could seek to enforce the mandate could "assert injury from governmental action taken in excess of the authority that federalism defines." 91 The Supreme Court has recently clarified that the rights asserted in such an action "do not belong to a State," but would belong personally to affected individuals. ${ }^{92}$ As the Supreme Court stated in Bond v. United States (decided after the district courts ruled on state standing in Virginia v. Sebelius and Florida v. HHS), "An individual has a direct interest in objecting to laws that upset the constitutional balance between the National Government and the States when the enforcement of those laws causes injury that is concrete, particular, and redressable." 93

88. Id. at 18 (emphasis omitted). The Court also noted that the claimed injury was not imminent. Id.

89. The federal government has also argued in Florida $v$. HHS that the claimed injury is speculative, and neither actual nor imminent. According to the federal government, the premandate status quo already imposes costs on the states in the form of uncompensated care; moving more people into insurance, for which states will bear some cost through Medicaid, may result in a net reduction of costs borne by the states. See Memorandum in Support of Defendants' Motion to Dismiss at 31, Florida v. HHS, 780 F. Supp. $2 \mathrm{~d} 1256$ (No. 3:10-cv-91-RV/EMT), 2010 WL 2663348 (addressing state injury-to-fisc standing theory). This consideration underscores the soundness of the federal government's reliance on circuit court decisions holding that the indirect economic effects of certain federal legislation on the state fisc were "so distantly related to the wrong for which relief is sought, as not to be cognizable for purposes of standing." Id. at 31-32 (quoting Pennsylvania v. Kleppe, 533 F.2d 668, 672 (D.C. Cir. 1976)); see also lowa ex rel. Miller v. Block, 771 F.2d 347, 353-54 (8th Cir. 1985) (holding that a state lacked Article III standing to sue on its own behalf because the effect on the state fisc was too attenuated).

90. See Ann Woolhandler \& Michael G. Collins, State Standing, 81 VA. L. REV. 387, 491 n.420 (1995); see also id. at 505-08 (explaining in more detail the benefits of a focus on legally protected interests in assessing state standing).

91. Bond v. United States, 131 S. Ct. 2355, 2363-64 (2011).

92. Id. at 2364 .

93. Id. 
Although Bond does not squarely address the issue of state standing, the Court's opinion carefully distinguishes between the state interests protected by federalism, on the one hand, and the availability of a federal judicial forum to vindicate those interests, on the other hand. The derivative nature of the allegedly standing-conferring injury identified by the states in Florida $v$. HHS supplies a prudential reason to deny such a forum to the states to challenge the individual mandate. ${ }^{94}$

The states' second theory of standing in Florida v. HHS depends on the alleged inseverability of the individual mandate. The states have asserted that they suffer injury from other provisions in the Act that regulate them as states, such as the Medicaid and employer mandate reforms. They argue that this injury can be remedied through invalidation of the entire Act, which would follow from a holding that the individual mandate is unconstitutional and inseverable. $^{95}$ In short, the states attempt to use an assertion of inseverability to leverage their acknowledged standing to challenge parts of the Act that do apply to them into standing to challenge a part that does not.

The states' standing-through-asserted-inseverability argument relies on a misreading of the Supreme Court's decision in Alaska Airlines, Inc. v. Brock. ${ }^{96}$ The Supreme Court in Alaska Airlines addressed the severability of a legislative veto provision from a statute that governed the transition to deregulated operation of airlines. ${ }^{97}$ A group of airlines challenged regulations regarding the rehiring of employees who had been furloughed or otherwise terminated. ${ }^{98}$ They contended that the statute authorizing the promulgation of those regulations contained an invalid legislative veto. ${ }^{99}$ The states in Florida v. HHS have described Alaska Airlines as a case in which the Court adjudicated a claim that an "entire statute was invalid as a result of [an] unconstitutional legislative veto

\footnotetext{
94. Woolhandler and Collins explain further:
}

As part of the existing common law of standing, the fact that other potential litigants are the more immediate objects of alleged illegal behavior and have incentives to sue is a factor weighing against finding a litigable interest. A related and unexceptionable presumption is that constitutional rights ordinarily belong to people even when the question concerns the structure of government. To the extent that individuals have legally protected interests and incentives to sue, state standing would usually be derivative of that of its citizens-as it is in tax collector standing and many applications of parens patriae standing. Accordingly, in these areas state standing need not readily be recognized.

Woolhandler \& Collins, supra note 90, at 507-08 (footnotes omitted); see also Ill. Dep't of Transp. v. Hinson, 122 F.3d 370, 373 (7th Cir. 1997) (Posner, C.J.) ("The main contemporary reason for having rules of standing, besides minimizing judicial caseloads and judicial interference with the life of the nation, is to prevent kibitzers, bureaucrats, publicity seekers, and 'cause' mongers from wresting control of litigation from the people directly affected ...." (citations omitted)).

95. Opening/Response Brief of Appellee/Cross-Appellant States, supra note 86, at 68.

96. See id. at 68-69 (arguing for standing based on inseverability in reliance on Alaska Airlines, Inc. v. Brock, 480 U.S. 678, 684-86 (1987)).

97. Alaska Airlines, 480 U.S. at 680.

98. Id. at 681-83.

99. Id. at 682-83. 
provision, where plaintiffs alleged injury based on other portions of the statute." 100 This description is misleading. The unconstitutional legislative veto was contained in one of the statutory provisions governing how the challenged regulations themselves were to be promulgated. As the trial court in that case explained, "the statutory language directly links the admittedly unconstitutional provision [i.e., the legislative veto] with the specific grant of rulemaking authority under attack."101 Alaska Airlines is therefore far removed from the circumstances facing the states who seek to challenge the individual mandate in Florida v. HHS on the basis of statutory provisions dealing with different matters in different sections of comprehensive legislation. The decision provides no precedent for the use of inseverability to generate a justiciable challenge to a statutory section that does not apply to the states seeking to challenge the individual mandate in Florida $v$. HHS.

In fact, precedent points in the opposite direction. When the Supreme Court has entertained assertions of inseverability in ascertaining the permissible scope of a challenge, the Court has limited its consideration to asking whether the particular provisions applicable to the challenging party in that particular case were inseverable. In Communist Party of the United States v. Subversive Activities Control Board, ${ }^{102}$ and Electric Bond \& Share Co. v. SEC, ${ }^{103}$ the government brought enforcement actions against organizations that failed to register as required by statute. In both cases, the Supreme Court considered only whether the provisions that the federal government sought to apply in those enforcement actions were inseverable from other parts of the challenged statutes. ${ }^{104}$ The Court refused to consider other provisions that the government did not seek to apply in those cases. ${ }^{105}$

To illustrate with a simple example, suppose a statute $(X Y)$ that is composed of two provisions ( $X$ and $Y$ ). Suppose, further, that $X$ imposes enforceable obligations on $P$, but $Y$ does not. $P$ can use inseverability to seek the invalidation of $X Y$ on the ground that $X$ is unconstitutional and it is inseverable from $Y$. But $P$ may not use inseverability to seek the invalidation of $X Y$ on the ground that $Y$ is unconstitutional and it is inseverable from $X$. Comparing this example with the statutes in the Electric Bond \& Share Co. and Communist Party cases, the registration provisions correspond to $X$, and the other challenged provisions 69.

100. Opening/Response Brief of Appellee/Cross-Appellant States, supra note 86, at 68-

101. Alaska Airlines, Inc. v. Donovan, 594 F. Supp. 92, 96 (D.D.C. 1984), rev'd, 766 F.2d 1550 (D.C. Cir. 1985); see also id. at 95 ("[T] he Court is faced here not with a legislative veto provision which applies to an entire statute, but with a veto provision applicable to one, and only one, particular section of a long and comprehensive piece of legislation.").

102. 367 U.S. 1 (1961).

103. 303 U.S. 419 (1938).

104. See Communist Party, 367 U.S. at 70-81; Electric Bond \& Share Co., 303 U.S. at 433-39.

105. See Communist Party, 367 U.S. at 81; Electric Bond \& Share Co., 303 U.S. at 443. 
correspond to $Y$. The Court considered the potential inseverability of $X Y$ using $X$ as a starting point, but refused to do so with respect to $Y$. Based in part on its determinations about $X$, the Court concluded that the challengers brought an unripe challenge or sought an advisory opinion on a hypothetical state of facts with respect to $Y$.

This analysis of precedent depends on the premise that inseverability is not reciprocal. The Supreme Court has not, so far as my research has revealed, explicitly observed that this is so. But the nonreciprocal nature of inseverability flows logically from established doctrine. When determining whether removal of a part will cause collapse of an entire edifice, it matters whether the part to be removed is a corner stone or a cornice stone. Likewise, when a court asks whether the constitutional remainder of a partially unconstitutional statute may function consistently with legislative intent after it holds a provision unconstitutional, the answer depends on which provision has been held unconstitutional.

The Supreme Court's unwillingness to entertain an inseverability argument arising out of statutory provisions inapplicable to the parties raising a constitutional challenge makes good sense. Federal statutes are often composed of all manner of unrelated provisions. If a party affected by any one of those provisions could gain standing by pointing to a constitutional defect in any other provision (regardless of whether that other provision could ever be applied against that party), then standing doctrine would be reduced to a sport for clever counsel. ${ }^{106}$ But federal courts do not exercise a general supervisory power over legislation. Judicial review is more like statutory Jenga, in which a court removes only what it must while attempting to keep the rest standing.

If asserted inseverability were enough for standing, constitutional litigation would have taken a different path long before now. For example, the Supreme Court almost certainly would have decided the constitutionality of the legislative veto before its use against Jagdish Rai Chadha provided him with standing to challenge it. ${ }^{107}$ Just as it took a private individual affected by the exercise of a legislative veto to bring a separation of powers challenge to it, so too will it take a private individual subject to the individual mandate to challenge it in federal court. ${ }^{108}$ The next Part explains why this doctrinal state of affairs is a good one.

106. Cf. Lewis v. Casey, 518 U.S. 343,357 (1996) ("The actual-injury requirement would hardly serve the purpose ... of preventing courts from undertaking tasks assigned to the political branches[,] if once a plaintiff demonstrated harm from one particular inadequacy in government administration, the court were authorized to remedy all inadequacies in that administration.").

107. See INS v. Chadha, 462 U.S. 919, 968 (1983) (White, J., dissenting) (explaining that Congress had included a legislative veto in more than 200 statutes in the preceding fifty years).

108. Cf. Bond v. United States, 131 S. Ct. 2355, 2365 (2011) ("[T]he claims of individuals-not of Government departments-have been the principal source of judicial decisions concerning separation of powers and checks and balances."). When the Eleventh Circuit decided Florida v. HHS on appeal, it declined to address any of the arguments regarding the 


\section{THE INSULATION ARISING OUT OF INCIDENTAL REVIEW}

Virginia v. Sebelius was born in political warfare. The lawsuit exists because Virginia enacted the Health Care Freedom Act, a state law enacted to counter a conflicting federal law by providing a vehicle for attacking the federal law in federal court. As invoked in Virginia v. Sebelius, the function of this antimandate statute has been to move debate over the federal individual mandate from the political realm to the legal realm. If successful, this move would enable Virginia to obtain federal judicial validation of the constitutional vision animating political and legal opposition to the individual mandate.

Although the occasion for this particular state law is the fight over health care reform, that is just one area in which the states are pushing back against the federal government. ${ }^{109}$ If Virginia's statute suffices on its own to establish federal jurisdiction, one can expect litigation-provoking statutes like the Health Care Freedom Act to proliferate.

To treat such statutes as tickets into federal court, however, would deprive the courts of an important buffer from political forces that federal justiciability doctrine currently provides. That doctrine requires that constitutional adjudication be incidental to resolution of a case or controversy, rather than that the case or controversy be incidental to resolution of a constitutional question.

absence of jurisdiction over the states' challenge to the individual mandate. Florida ex rel. Attorney Gen. v. U.S. Dep't of Health \& Human Servs., 648 F.3d 1235, 1243 (11th Cir. 2011), cert. granted sub nom. Florida v. Dep't of Health \& Human Servs., 80 U.S.L.W. 3199 (U.S. Nov. 14, 2011) (Nos. 11-393, 11-398, 11-400). The court reasoned that it is sufficient that "at least one plaintiff has standing to raise each claim," a condition that was met by the private plaintiffs with respect to the individual mandate. $I d$. The court correctly stated the principle, but was too quick to rely on it and to dismiss as "academic," $i d$., the justiciability problems with the states' challenge to the individual mandate. That is because the Eleventh Circuit's conclusion that the private plaintiffs' challenge was within federal jurisdiction may have been mistaken. In Liberty University, Inc. v. Geithner, the United States Court of Appeals for the Fourth Circuit held that the Tax Anti-Injunction Act bars pre-enforcement challenges to the individual mandate. No. 10-2347, 2011 WL 3962915, at *14-16 (4th Cir. Sept. 8, 2011). The Eleventh Circuit did not address the Tax Anti-Injunction Act in its ruling. But if the Fourth Circuit's conclusion in Liberty University is correct, then there is no federal jurisdiction over the private plaintiffs' challenge to the individual mandate in Florida v. HHS, and federal jurisdiction depends on the states' alternative standing theories.

109. See The Tenth Amendment Nullification Movement, TENTH AMENDMENT CENTER, $\mathrm{http} / / / \mathrm{www}$. tenthamendmentcenter.com/the-10th-amendment-movement (last visited Jan. 14, 2012) (providing resources for tracking state legislation challenging federal laws regulating firearms, food, and marijuana, among other items). Some of the state legislation relies on an asserted state authority to regulate intrastate commerce free of federal regulation. For example, Texas has enacted a law providing that incandescent light bulbs manufactured in the state are not subject to federal regulation. See TEX. BUS. \& COM. CODE ANN. § 2004.001 (West 2011). As of October 2011, similar bills had been introduced in Arizona, Georgia, Michigan, and South Carolina. See Chris Christoff, Bulbs Rally Lawmakers in Fight for State Rights, BLOOMBERG (Oct. 16, 2011, 9:01 PM), http://www.bloomberg.com/news/2011-10 $-17 /$ bulbs-rally-lawmakers-in-fight-for-state-rights.html. 
Insistence on constitutional adjudication as incidental to the resolution of a case or controversy is one of the strengths of the American legal system. Alexis de Tocqueville discerned early on that this feature of the system provided the judiciary some insulation from the buffeting of political winds. The power given the judiciary in America, he observed, was not to censure legislation in the abstract, but only to "refuse to admit [unconstitutional legislation] as a rule" in deciding a case. ${ }^{110}$ Tocqueville recognized that a less restricted power would subject the judge exercising it to enlistment in political controversy, "and as the champion or the antagonist of a party, he would have brought the hostile passions of the nation into the conflict." 111 The absence of a power to censure unconstitutional legislation in the abstract may be problematic at times, such as when delay creates uncertainty, or when individuals are required to comply with a law later held to be unconstitutional. Tocqueville understood, however, that Americans "have left the remedy incomplete, lest they should give it an efficacy that might in some cases prove dangerous." 112

Tocqueville was right. Justiciability doctrine functions in various ways to insulate the federal judiciary-at least somewhat-from political forces. There are longstanding debates over the legitimacy of consciously shaping justiciability doctrine to achieve this end. ${ }^{113}$ But if it were possible to invoke federal jurisdiction solely on the basis of a state statute opposing a particular rule of federal law, the insulation provided by that doctrine would be eliminated in exactly those cases where insulation from political pressures would be needed most - those involving highly controversial issues that have mobilized a political constituency to push successfully for state legislation designed to seek invalidation of federal law. This concern is not why the Supreme Court decided Franchise Tax Board and Skelly Oil as it did, but it is nonetheless a strong reason for courts to apply their holdings to foreclose suits like Virginia v. Sebelius.

110. 1 AleXIS DE TOCQUeVILle, Democracy in AMERICA 101 (Phillips Bradley ed., Henry Reeve trans., Alfred A. Knopf 1980) (1835).

111. Id. at 102. Protection from this enlistment arises out of the fact that the American judge enters the political arena "independently of his own will. He judges the law only because he is obliged to judge a case. The political question that he is called upon to resolve is connected with the interests of the parties, and he cannot refuse to decide it without a denial of justice." Id. at 103.

112. Id. at 103.

113. For a classic debate over the relative weight to be accorded this consideration, compare AleXANDER M. Bickel, The Least Dangerous BRANCH: THE SUPREME COURT AT THE BAR OF POLITICS 111-98 (1962) (discussing various means by which the Supreme Court can and should accommodate its enforcement of constitutional principle to political and practical realities), with Gerald Gunther, The Subtle Vices of the "Passive Virtues"-A Comment on Principle and Expediency in Judicial Review, 64 COLUM. L. REV. 1, 25 (1964) (identifying problems with Bickel's accommodationism). It is also worth noting here, as Samuel Bray has observed, that the "passive virtues" advocated by Bickel-which are "mediating techniques' and devices for 'not doing"'--stand in some tension with the justifications offered for the sort of "preventive adjudication" enabled by declaratory judgment actions. See Samuel L. Bray, Preventive Adjudication, 77 U. CHI. L. REV. 1275, 1314 (2010). 
If federal jurisdiction can be premised solely on a state statute like Virginia's Health Care Freedom Act in this first case, it assuredly will not be the last. And as the events surrounding the case have already borne out, the combination of political pressures and abstract adjudication in a case like Virginia $v$. Sebelius can generate strong currents. While the federal courts can withstand the pull of those currents in any one case, there is a real risk that a proliferation of such cases could generate currents too strong to withstand.

Consider the effects of Virginia $v$. Sebelius at the district court level alone. Immediately upon issuance of a judgment in Virginia's favor, legal and political figures across the nation hailed the decision as a game changer that cemented the seriousness of the constitutional objections leveled against the individual mandate. ${ }^{114}$ Others, it is true, sought to minimize the decision's importance. ${ }^{115}$ But even these attempts at minimization are a testament to the consequential nature of the decision. For example, Attorney General Eric Holder and Secretary of Health and Human Services Kathleen Sebelius apparently thought the decision significant enough to publish a jointly authored op-ed in the next day's Washington Post. ${ }^{116}$

114. See, e.g., Kevin Sack, Years of Wrangling Lie Ahead for Health Care Law, N.Y. TIMES, Dec. 14, 2010, at A24 ("[T] he challenges from dozens of states to the law's constitutionality can no longer be dismissed as frivolous, as they were earlier this year by some scholars and Democratic partisans."); Sheryl Gay Stolberg, Just One Ruling, but an Outsize One, N.Y. TIMES, Dec. 14, 2010, at A24 ("By the numbers, President Obama is beating opponents of his signature health care bill two to one in federal court. Of the three district court judges who have ruled on the merits of constitutional challenges to the landmark Affordable Care Act, two have sided with Mr. Obama. But from a political standpoint, the only case that really matters is the one Mr. Obama lost on Monday."); Randy Barnett, A Noxious Commandment, N.Y. TIMES ROOM FOR DEBATE (Dec. 13, 2010), http://www.nytimes.com/roomfordebate/2010/12/13/a-fatal-blow-to-obamas-health-care -law/an-unconstitutional-commandment ("The days of calling the constitutional challenges to the Affordable Care Act 'frivolous' and 'political' are now officially over. Judge Hudson's ruling that the individual insurance mandate is unconstitutional is a milestone in the legal process of deciding whether Congress has the power to command every person in the United States to enter into an economic relationship with a private company."); Ashby Jones, The Health Care Law Under the Judicial Knife: Some Early Reactions, WALL ST. J. L. BLOG (Dec. 13, 2010, 2:20 PM), http://blogs.wsj.com/law/2010/12/13/the-health-care-law-under -the-judicial-knife-some-reactions ("This is a momentum-changer that will further tarnish the Obama administration as it faces serious legal challenges to the President's most noteworthy legislative accomplishment, which now faces a 112th Congress filled with Republicans who have pledged to repeal the unpopular health care reforms." (quoting Jordan Sekulow, Director of Policy at the American Center for Law \& Justice)).

115. See Jennifer Haberkorn \& Scott Wong, Health Ruling Is GOP Rallying Cry, POLITICo (Dec. 14, 2010, 6:52 AM), http://www.politico.com/news/stories/1210/46319.html ("Lawmakers pounced on the news Monday that a federal judge has struck down health reform's individual mandate-with Republicans welcoming it as a body blow to 'Obamacare' and Democrats dubbing it a detour on the road to reform.").

116. Eric H. Holder, Jr. \& Kathleen Sebelius, Op-Ed., Health Reform Will Survive Its Legal Fight, WASH. POST, Dec. 14, 2010, at A23. 
In the political realm, the district court's decision in Virginia $v$. Sebelius became a rallying point for legislators opposed to the Patient Protection and Affordable Care Act, and assertions about the Act's unconstitutionality became a staple in arguments for its repeal. The district court's decision had a significant effect in the legal realm as well, although not as outsized as in the political realm. Legal commentators on both sides of the issue gravitated to the district court's opinion as a focal point for analysis, even while these commentators (and the district court itself) recognized that the decision is not binding on any other court and is not the final word on the matters it addresses.

The decision's many effects cannot, in truth, be neatly divided between the legal and political realms. Given the nature of the case, any effort to draw a clear boundary between the two realms and then to assign some features of the case to one or the other breaks down. To what realm, for instance, should one allocate the Internet display advertisements by Attorney General Cuccinelli's political committee that ran both on the day that summary judgment was argued and also on the day that the summary judgment decision was handed down? ? $^{17}$ It might be tempting to dismiss these advertisements as purely political. But that quick characterization would neglect the extent to which the legal skirmishing in Virginia $v$. Sebelius is just one front in a larger battle of ideas about the Constitution-one in which the line between legal and political has never been neatly drawn. ${ }^{118}$

117. On October 18,2010, the author of this Article observed display advertisements for Ken Cuccinelli's political website on news and commentary sites while Virginia's solicitor general was in Judge Hudson's courtroom for arguments over summary judgment. The advertisements contained a headshot of Virginia's Attorney General, with the message that "liberty is under attack, and I am attacked for defending it." See Stop the Mandate, CUCCINELLI.COM, http://www.cuccinelli.com/petition/landing/support_petition.html (last visited Jan. 14, 2012). The link took visitors to a page headlined "Stop the Mandate," with the message: "Hi I'm Ken Cuccinelli and 15 minutes after President Obama signed the health care law my office filed suit to overturn the individual mandate. Will you join me?" Id. The page invited visitors to sign a petition and linked to a donation page.

As on the day summary judgment was argued in Virginia $v$. Sebelius, so too on the day that summary judgment was granted: Virginia Attorney General Ken Cuccinelli's political committee sponsored display advertisements trolling for supporters and donations, this time touting victory and basking in the validation provided by the ruling. See Ben Smith, Cuccinelli Fundraising off Health Care Win, PolITICO (Dec. 13, 2010, 3:41 PM), $\mathrm{http} / / / \mathrm{www}$.politico.com/blogs/bensmith/1210/Cuccinelli_fundraising_off_health_care_win .html ("That didn't take long: Virginia Attorney General Ken Cuccinelli is already capitalizing on today's health care victory with a big online fundraising push, with this image on top of the Drudge Report and on Google Ads across the political web. The ad takes supporters to a petition ... which harvests their emails and then, naturally, to a 'Donate' button.").

118. Indeed, this is how Attorney General Cuccinelli and his political director have explained the advertisements. See Rosalind S. Helderman, Va. Attorney General Cuccinelli's Strategy Looks Good in Light of Ruling, WASH. POST, Dec. 14, 2010, at B1 ("'There's a battle of ideas going on here,' [Attorney General Cuccinelli] said. 'The formal battle is going on in court. There's also a battle for hearts and minds the citizenry [sic]. I'm trying to educate folks about why we're doing this."'); id. (describing political director Noah Wall's explana- 
Moreover, even if one were to view the lawsuit as largely political, it would be mistaken to characterize it as an activist Attorney General's one-man crusade. The Health Care Freedom Act passed through Virginia's General Assembly on a bipartisan basis. ${ }^{119}$ And the popular sensibility addressed by the Virginia legislature was not peculiarly Virginian. A nationwide poll in August 2010 revealed that $70 \%$ of Americans had an unfavorable view of the individual mandate, including $52 \%$ of Americans who characterized their view as strongly unfavorable. ${ }^{120}$ Legal measures opposing various aspects of health care reform were introduced in over forty state legislatures in 2009 and 2010, and Virginia was just one of seven states to enact opposition to an individual mandate into state law in 2010. ${ }^{121}$ Oklahoma, which added an antimandate provision to its constitution in 2010, filed a go-it-alone lawsuit similar to Virginia v. Sebelius, in reliance on its constitutional amendment. ${ }^{122}$

State standing to challenge the individual mandate is not exclusive of individual standing, of course, and the first appellate court ruling on the constitutionality of the individual mandate came in a case with no state plaintiffs. ${ }^{123}$ Yet the prominence of the state challenges has tinted the individual liberty aspect of limits on federal legislative power with the hue of political posturing. This coloring affects perceptions not only of the litigants but also of the federal courts themselves.

The portion of the Fourth Circuit opinion that drew the sharpest response from Virginia's Attorney General in reacting to the opinion after it was issued was the court's explanation of its refusal to accept a theory that would turn each state into "a roving constitutional watchdog of sorts." 24 According to Attorney General Cuccinelli, "This was exactly a role that the Founding Fathers planned

tion that "the goal of the ads was not to raise money but to encourage supporters to sign a petition expressing support").

119. See Olympia Meola \& Tyler Whitley, Va. Response to Overhaul Practical and Ideological, Rich. TIMES-DISPATCH, Sept. 26, 2010, at A1 (stating that four Senate Democrats voted with Republicans in passing the Health Care Freedom Act); What's Happening at the Capitol Today?, RICH. TIMES-DISPATCH, Mar. 11, 2010, at A9 (noting that a majority of thirty-nine House Democrats voted with Republicans in passing the Health Care Freedom Act).

120. Henry J. Kaiser Family found., Kaiser Health Tracking Poll 7 (2010).

121. See Richard Cauchi, State Legislation and Actions Challenging Certain Health Reforms, 2009-2010, NAT'L CONF. ST. LeGislatures (Mar. 14, 2011), http://www.ncsl.org/?Tabld=22375; Richard Cauchi, State Legislation and Actions Challenging Certain Health Reforms, 2011, NAT'L CONF. ST. LeGISLATURES (Sept. 9, 2011), http://www.ncsl.org/?tabid=18906. The other states enacting a mandate-exemption statute in 2010 were Arizona, Georgia, Idaho, Louisiana, Missouri, and Utah. Id.

122. Complaint for Declaratory and Injunctive Relief at 1, 2, 7, Oklahoma ex rel. Pruitt v. Sebelius, No. 6:11-cv-00030-RAW (E.D. Okla. Jan. 21, 2011); see also Kevin Sack, $O k$ lahoma: State Will Challenge Health Care Law, N.Y. Times, Jan. 8, 2011, at Al4.

123. See Thomas More Law Ctr. v. Obama, 651 F.3d 529, 529 (6th Cir. 2011), petition for cert. filed, 80 U.S.L.W. 3065 (U.S. July 26, 2011) (No. 11-117).

124. Virginia ex rel. Cuccinelli v. Sebelius, 656 F.3d 253, 272 (4th Cir. 2011), petition for cert. filed, 80 U.S.L.W. 3221 (U.S. Sep. 30, 2011) (No. 11-420). 
for the states to have."125 The Attorney General's statement continued: "As James Madison wrote, under the Constitution, "the power surrendered by the people is first divided between two distinct governments . . . . Hence a double security arises to the rights of the people. The different governments [state and federal] will control each other....",126

Attorney General Cuccinelli's invocation of a truncated version of Madison's statement in Federalist No. 51 captures the essence of what was wrong with Virginia $v$. Sebelius from the outset. The "double security" famously described by Madison consists of both federalism (i.e., the division into two distinct governments) and separation of powers (i.e., the distribution of federal power to distinct departments). The ellipses in the portion quoted by Attorney General Cuccinelli reveal that something is missing, and that something turns out to be Madison's discussion of separation of powers. ${ }^{127}$ The omission captures in miniature the problem with Virginia's rush to assert a federalism objection in federal court relying solely on Virginia's Health Care Freedom Act: it neglected the limits placed on the federal judicial power in Article III of the Constitution. These limits, as the Supreme Court has repeatedly explained, are essential to the Constitution's distribution of legislative, executive, and judicial power "among distinct and separate departments." 28

\section{CONCLUSION}

Because Virginia is not the only state to have enacted opposition to the federal individual mandate into state law, and because health care is just one

125. Press Release, Office of the Attorney Gen., Cuccinelli Expresses Disappointment in Fourth Circuit's Ruling in Health Care Case (Sept. 8, 2011), available at http:// www.oag.state.va.us/Media\%20and\%20News\%20Releases/News_Releases/Cuccinelli/981 1 Health_Care_Ruling.html.

126. Id. (alteration in original) (quoting THE FeDERALIST No. 51, at 323 (James Madison) (Clinton Rossiter ed., 1961)).

127. The sentence immediately preceding the language quoted by the Attorney General states: "In a single republic, all the power surrendered by the people is submitted to the administration of a single government; and the usurpations are guarded against by a division of the government into distinct and separate departments." THE FEDERALIST No. 51 (James Madison), supra note 126, at 323 . The next sentences read as follows (with the language absent from the Attorney General's press release marked by a strike-through):

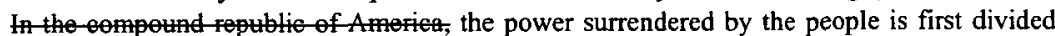

between two distinct governments, and then the pertion alloted-to onoh-sublivided ameng

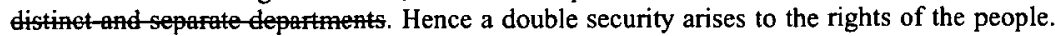

The different governments will control each other, at the same-thom trolted by itself.

Id.; Office of the Attorney Gen., supra note 125.

128. THE FEDERALIST No. 51 (James Madison), supra note 126, at 323; see also, e.g., DaimlerChrysler Corp. v. Cuno, 547 U.S. 332, 341 (2006) ("This Court has recognized that the case-or-controversy limitation is crucial in maintaining the "tripartite allocation of power' set forth in the Constitution." (quoting Valley Forge Christian Coll. v. Ams. United for Separation of Church \& State, Inc., 454 U.S. 464, 474 (1982))). 
issue on which the states are pushing back against the federal government, the correct approach to federal jurisdiction in a case like Virginia v. Sebelius has broad significance. This Article has explained why current doctrine requires dismissal, and has further suggested why this is desirable from the point of view of the federal courts.

The arguments in this Article do not reduce to an argument for a rule of federal jurisdiction that would authorize federal court refusal to entertain claims because state officials may be using the forum to further their own political ambitions. Such a rule would be impossible to apply, given the inevitable intermixture of political and legal considerations in actions brought by elected public officials. And, after all, elected public officials should be eager to enforce the will of the people as expressed in their laws. Moreover, even if such a rule could be applied, it would be a bad idea to have it. The use of federal courts as vehicles of political ambition is an important source of the courts' power to maintain some control over determinations of constitutional meaning. 129

Nor do the arguments in this Article stem from angst about messy public debates over constitutional meaning. The worry, instead, is about what might flow from the immediate thrusting of all such debates into federal courts without regard to established jurisdictional doctrine. The aim is to preserve the rules of federal jurisdiction that enable the federal judiciary to stand firm against the political and cultural waves that continually cast questions of constitutional meaning out of the swirling tides of political processes onto the hard land of the judicial domain. The law should not prevent these questions from ever coming ashore, but should instead ensure that they arrive there in a way that does not threaten erosion of the shore into the sea.

Curbing the overt politicization of abstract review in federal court was not the intended function of the Court's rulings in Skelly Oil and Franchise Tax Board. But that may nevertheless be the most beneficial function of straightforwardly applying to Virginia $v$. Sebelius the Supreme Court's pronouncement that " $[\mathrm{t}]$ he situation presented by a State's suit for a declaration of the validity of state law is . . not within the original jurisdiction of the United States district courts." 130

The declaratory judgment remedy has many virtues, but Felix Frankfurter was right to worry early on that its casual acceptance could cause federal courts to issue forbidden advisory opinions. The district court's decision in Virginia $v$. Sebelius is a case in point. Virginia's lawsuit conjured, for a time, the phantom feared by Frankfurter-a ghost that slays. ${ }^{131}$ As long as the courts remain vigi-

129. See generally KeITH E. WhitTington, Political Foundations of Judicial SUPREMACY: THE PRESIDENCY, THE SUPREME COURT, AND CONSTITUTIONAL LEADERSHIP IN U.S. HISTORY 18 (2007).

130. Franchise Tax Bd. v. Constr. Laborers Vacation Trust, 463 U.S. 1, $21-22$ (1983).

131. See Frankfurter, supra note 2, at 1008. 
lant, however, there is reason to hope that neither this poltergeist nor similar spectral beings will haunt the halls of the federal courts.

\section{POSTSCRIPT: A REPLY TO VIRGINIA'S MANDATE-CHALLENGE TRIUMVIRATE}

Attorney General Cuccinelli, Solicitor General Getchell, and Deputy Attorney General Russell (collectively, the Attomey General) devote only a small portion of their invited article to the arguments in The Ghost That Slayed the Mandate. This Postscript in reply can be correspondingly brief.

The Attorney General first attributes significance to the fact that "Franchise Tax Board is a removal case." 132 That feature of the case is irrelevant, however, because removal jurisdiction depends on original jurisdiction. Franchise Tax Board itself is a case that was not removable precisely because it was not within the original jurisdiction of the federal district courts. Hence the Supreme Court's statement in that case that " $[\mathrm{t}] \mathrm{he}$ situation presented by a State's suit for a declaration of the validity of state law is . . . not within the original jurisdiction of the United States district courts. Accordingly, the same suit brought originally in state court is not removable either." 133

The Attorney General next argues that the Franchise Tax Board objection to statutory subject matter jurisdiction rests on the mistaken premise that the only relief sought by Virginia is a declaration that its law is valid. That is inaccurate. There has never been any question that Virginia also seeks to enjoin enforcement of the federal individual mandate. ${ }^{134}$ The problem is that the Attorney General's claimed right to come into federal court on behalf of the Commonwealth depends on the existence of Virginia's antimandate law. Indeed, the Attorney General conceded this point in arguing that "[t]he Virginia law transforms Tenth Amendment issues of the sort found to be merely abstract in Mellon into an immediate and concrete dispute within the ambit of the sovereign standing cases." 135 The Attorney General is right to recognize that a state's naked claim that the individual mandate exceeds Congress's power is "merely abstract." The Attorney General is wrong, however, to assert that the mere coexistence of conflicting statutes is sufficient to transform a disagreement over sovereign authority from abstract to concrete.

132. Kenneth T. Cuccinelli et al., State Sovereign Standing: Often Overlooked, but Not Forgotten, 64 STAN. L. REV. 89, 117 (2012).

133. Franchise Tax Bd., 463 U.S. at 21-22.

134. See, e.g., Brief of Amicus Curiae Kevin C. Walsh in Support of Appellant Seeking Reversal at 9, Virginia ex rel. Cuccinelli v. Sebelius, 656 F.3d 253 (4th Cir. 2011) (Nos. 111057, 11-1058), 2011 WL 773573 [hereinafter Walsh Brief] (arguing that the relief Virginia seeks in addition to a declaratory judgment of state law validity "cannot be independently salvaged from its fatally flawed claim for declaratory relief'); supra text accompanying note 16 ("Virginia seeks a declaratory judgment that its state law remains valid notwithstanding the individual mandate in the federal law, along with injunctive relief prohibiting enforcement of the entire healthcare reform Act.").

135. Appellee's Opening and Response Brief, supra note 38, at 18 (emphasis added). 
The Attorney General next claims that "[n]o serious argument can be made that the federal courts lack the jurisdiction to find federal statutes unconstitutional." 136 I disagree. Every lawsuit that seeks an advisory opinion about the constitutionality of a federal statute is outside of federal jurisdiction. Every constitutional challenge to a federal statute in which the plaintiff lacks standing is one in which the federal courts lack the jurisdiction to find federal statutes unconstitutional. Quite simply, the claim that a federal law is unconstitutional is not a sufficient condition for federal jurisdiction in all circumstances.

The Attorney General's response to the Skelly Oil argument for lack of jurisdiction lacks a critical ingredient. The Skelly Oil argument has two steps. First, I argue Virginia must show that it is entitled to seek some type of nondeclaratory relief. The Attorney General does not dispute the argument at this first step. Second, I argue that there is no type of nondeclaratory relief that Virginia is authorized to seek. The Attorney General does not dispute that Virginia may not seek injunctive relief either (i) to enjoin application of the individual mandate to Virginia's citizens, or (ii) to enjoin application of the individual mandate to Virginia itself. But the Attorney General nevertheless asserts that applying Skelly Oil to demonstrate the absence of statutory subject matter jurisdiction in Virginia v. Sebelius "falls into the fallacy of the excluded middle."137 To support this assertion with argument, it would be necessary for the Attorney General to show that Virginia is entitled to seek some type of nondeclaratory relief other than what my analysis has shown to be unavailable. This the Attorney General neither does, nor even attempts.

Instead, the Attorney General contends that my formulation of the Skelly Oil argument "misunderstands and misstates the nature of the sovereign injury suffered and claimed by Virginia." 138 That is incorrect. ${ }^{139}$ Regardless, the contention is nonresponsive. Disputing how to characterize Virginia's injury does not answer the Skelly Oil objection grounded in Virginia's inability to seek nondeclaratory relief without running afoul of some other jurisdictional barrier (like the Mellon bar on parens patriae standing against the federal government or the prohibition of advisory opinions).

The Attorney General asserts at one point that my Fourth Circuit amicus curiae brief "focused exclusively on the standing question." ${ }^{40}$ Like The Ghost That Slayed the Mandate, however, the bulk of the amicus filing focused on statutory subject matter jurisdiction, while the Article III analysis addressed advisory opinion doctrine and the redressability prong of standing analysis. ${ }^{141}$ Although most of the Attorney General's arguments about state sovereign

136. Cuccinelli et al., supra note 132, at 118.

137. Id.

138. Id.

139. See supra text accompanying notes $22-24$.

140. Cuccinelli et al., supra note 132, at 116.

141. See Walsh Brief, supra note 134 , at i. 
standing do not deal with the other jurisdictional problems identified in The Ghost That Slayed the Mandate, those standing arguments nevertheless merit a brief reply.

The Attorney General equates a state's authority to defend its laws when attacked in a case or controversy with the existence of a case or controversy any time federal law and state law conflict on paper. That is a fundamental error. The Attorney General writes:

Virginia claims a right to legislate and has actually legislated in an area that is now also occupied by PPACA's mandate and penalty. If the mandate and penalty exceed the limits of congressional power, the federal law is invalid. Thus, there is an actual case or controversy with respect to that issue that is not dependent on the remedy provided by the Declaratory Judgment Act. ${ }^{142}$

The argument appears to be that there is a case or controversy because state and federal law conflict, and the federal law is invalid if it is unconstitutional. Thus formulated, the Attorney General presents nothing more than a words-onpaper conflict between state and federal law. The Attorney General's inability to explain away the abstract nature of the complaint-generating conflict remains.

A right to defend a state law attacked in an existing controversy is not equivalent to a right to use that state law to generate a case or controversy to attack conflicting federal law. The difference between the two is apparent when one looks at the Attorney General's principal modern authority on state sovereign standing, Diamond $v$. Charles. ${ }^{143}$

The Supreme Court's decision in Diamond $v$. Charles capped a case that began shortly after Illinois enacted a statute regulating abortion. ${ }^{144}$ Doctors who performed abortions challenged that statute as unconstitutional in a federal lawsuit against state officials charged with enforcing it. ${ }^{145}$ Diamond, a doctor opposed to abortion, intervened on the enforcement officials' side to defend the law. ${ }^{146}$ The district court preliminarily, and later permanently, enjoined enforcement of various provisions of the challenged statute. ${ }^{147}$ The court of appeals affirmed the injunction against enforcement of three provisions and further held that an additional provision's enforcement should be enjoined. ${ }^{148}$ The enforcement officials for Illinois chose not to appeal to the Supreme Court, but intervenor-defendant Diamond filed a notice of appeal and jurisdictional statement. ${ }^{149}$ The Supreme Court held that, in the absence of an appeal from the Illinois enforcement officials, there was no case or controversy upon which it

142. Cuccinelli et ai., supra note 132 , at 118-19.

143. 476 U.S. 54 (1986).

144. Id. at 57.

145. $I d$.

146. $I d$. at $57-58$.

147. $I d$. at 58-61.

148. Id. at 61 .

149. Id. 
could rule. ${ }^{150}$ The Court reasoned that, "[b]ecause the State alone is entitled to create a legal code, only the State has the kind of 'direct stake' identified in [the Court's standing doctrine] in defending the standards embodied in that code." 151

The Attorney General draws from Diamond $v$. Charles the proposition that "in defending its code of laws, a State has standing that others might lack." That proposition is unexceptionable so far as it goes. But it does not mean that a state has standing as a plaintiff to bring a suit to vindicate its law from conflicting federal law. The case or controversy in Diamond v. Charles did not depend on an abstract conflict between state and federal law. Rather, as the Supreme Court noted, the case or controversy was "[t]he conflict between state officials empowered to enforce a law and private parties subject to prosecution under that law." 153 The analogous case or controversy in the individual mandate context would be one between federal officials empowered to enforce the individual mandate and private parties subject to that mandate. That bears no resemblance to Virginia $v$. Sebelius, a state action against federal officials to challenge a provision not enforceable against the State of Virginia. Indeed, Virginia v. Sebelius does not include as a party anyone against whom the mandate could be enforced.

At bottom, Virginia v. Sebelius does not present a "case" or "controversy" under Article III. Whether one arrives at that conclusion by application of standing doctrine or advisory opinion doctrine, the conclusion about constitutional jurisdiction remains the same. These Article III problems compound the jurisdictional problems under Franchise Tax Board and Skelly Oil set forth at length above.

150. Id. at 62-71.

151. Id. at 65 (citation omitted).

152. Cuccinelli et al., supra note 132 , at 109.

153. Diamond, 476 U.S. at 64. 